\title{
In vitro Seed-dressing Technique for the Control of Seed-borne Fungi of Rice variety Faro -29
}

\author{
${ }^{1}$ IBIAM O.F.A; ${ }^{2}$ UMECHURUBA,C. I.; ${ }^{3}$ A. E ARINZE \\ Department of Applied Biology, Ebonyi State University, P.M.B.053 Abakaliki. Department of Plant Protection, Michael Okpara \\ University, Umudike., Department of Plant Science and Biotechnology, University of Port Harcourt, Choba. \\ drakanuibiamjr@yahoo.comTel.+234-0803-542-3334.
}

\begin{abstract}
Use of seed-dressing fungicides (Bavistin, Benlate, Fernasan-D, Apron Plus 50 DS and DithaneM45), and soaking and slurry methods at various concentrations, for the control of seed-borne fungi of rice variety Faro 29 in vitro, was investigated. The results obtained showed that all the fungicides significantly inhibited the seed-borne fungi associated with the seeds of the variety at concentrations of $40 \mathrm{~g} / \mathrm{ml}$, and $50 \mathrm{mg} / \mathrm{ml}(\mathrm{P}<0.05)$, in the soaking method, and at all the concentrations in the slurry method $(\mathrm{P}<0.05)$. The mean percentage seed germination, was not below $71 \%$, at all the concentrations in the two methods used. The relevance of this work to the production of rice and food security in Nigeria is discussed. @ JASEM
\end{abstract}

Control of fungal diseases through chemotherapy is receiving much attention as a result of its efficacy, and not having any deleterious effect on the vegetation and other components of the ecosystem. In the past, several fungicides have been employed in the control of fungal diseases of rice and other crops. Agrochemicals like Benlate, Bavistin, Apron Plus 50 DS, Fernasan-D and Dithane M-45 were used to control a number of diseases caused by fungal pathogens of rice. In 1987, Ou had reported that fungal pathogens constitute the major biological constraints in rice production, and new and potentially destructive species are being discovered every day. Ou, (1987), reported that several approaches were used to control these seed-borne fungi. According to Abda-El-Moity et al (1982), prolonged exposure of mycelia and conidia of $T$. harzianum to benomyl stopped the growth of the fungus. Narmada and Kang (1992), reported that laboratory evaluation of seed treatment of rice with Carbendazim (Bavistin) and thiram, controlled seed rot, and significantly decreased seed mortality. They stated that, in two different trials, Carbendazim at $2 \mathrm{~g} / \mathrm{kg}$ seeds, was the best of the 6 seed-dressing fungicides for improving germinability of discoloured rice. They further stated that $2 \%$ Carbendazim was the best of 9 sprays used for reducing infection $(81.2 \%)$ by $F$. moniliforme ( $G$. fujikuroi). $0.4 \%$ of the fungicide Fernasan-D was reported to be effective against seed-borne fungi by Ramanitham and Sivaprakasam, (1994). Seed treatment with $0.3 \%$ Carbendazim (Bavistin) $+0.3 \%$ thiram (Fernasan-D) to protect seeds, resulted in a distinct improvement in germination rate of rice seeds (Misra and Dharan, 1990).

Mancozeb (Dithane M-45 has been used solely, and in combination with other fungicides for the control of fungal diseases of rice. Mancozeb and Carbendazim were reported to be more effective than
Fernasan-D (thiram) in the reduction of disease intensity of Cochliobolus miyabeanus ( $B$ oryzae). The causal agent of brown spot of rice, in both wet and dry treatment (Lakshmanan and Mohan, 1988). They also stated that in the dry seed treatment, these fungicides increased seedling population and shoot length over the untreated controls; and that thiram and Mancozeb except Carbendazim, increased root-length. Treatment with Carbendazim $(0.2 \%)$ or Mancozeb $(0.3 \%)$ was reported to be effective against brown leaf spot caused by Helminthosporum oryzae (Bipolaris oryzae) by Geetha and Sivaprakasam, (1993).

Ibiam et al, (2000)and (2006), reported that seeddressing fungicides- Benlate, Apron plus 50 Ds, Fernasan-D, Dithane M-45 and Bavistin controlled seed-borne fungi of rice Fusarium moniliforme, Bipolaris oryzae, Trichoderma hazianum, Curvularia lunata, Fusarium oxysporum and Chaetomium globossum which both causes damage to rice both in the field and storage. They also reported that theses fungicides improved seed germination in vitro, seedling emergence in vivo and yield of the crop. This research is aimed at finding the possibility of controlling seed-borne fungi associated with the rice variety, Faro 29, by seedtreatment using these fungicides- Bavistin, Benlate, Fernasan-D, Apron plus 50 Ds, and Dithane M-45, with a view to increasing the production of the variety, and ensuring food security in Nigeria.

\section{MATERIALS AND METHODS}

\section{Soaking method}

For soaking method, the method of Gangopadhyay and Kapoor, (1977) was used with some modifications. $10 \mathrm{~g}$ of infected seeds of the variety were soaked in different concentrations of fungicides Apron Plus-50-Ds, Fernasan-D, Dithane-M45, Benlate, and Bavistin, $20 \mathrm{mg} / \mathrm{ml}, 30 \mathrm{mg} / \mathrm{ml}, 40 \mathrm{mg} / \mathrm{ml}$ 
and $50 \mathrm{mg} / \mathrm{ml}$, and left for 1 hour, to enable the seeds absorb the fungicides. After treatment, they were spread on sterile trays and air-dried for 30 minutes.

\section{Slurry method}

For slurry method, the method of Gangopadhyay and Kapoor (1975) was used with some modifications $.2 \mathrm{ml}$ of sterile distilled water was mixed with $10 \mathrm{~g}$ of seeds of each of the variety added to $20 \mathrm{mg}, 30 \mathrm{mg}, 40 \mathrm{mg}$ and $50 \mathrm{mg}$ of the fungicides, Apron Plus 50-DS, Fernasan-D, Dithane-M45, Benlate, and Bavistin, mixed properly, and air-dried for 30minutes on sterile tray to enable the seeds absorb the fungicides. Twenty five seed samples per method were incubated in complete darkness at $25 \pm 2{ }^{\circ} \mathrm{C}$ for seven days, after which period, they were examined under stereobinocular microscope at magnification $(6-50 \mathrm{x})$.The fungi observed were identified and characterized using the method of Burnett and Hunter, (1991). The control was soaked in sterile distilled water for $1 \mathrm{hr}$, and air-dried the same way as the other treatments. Potency or efficacy of the fungicides was determined in the form of $\%$ fungal recovery, using the following formula :

$\mathrm{P}$ or $\mathrm{E}=\underline{\mathrm{N}_{1}-\frac{\mathrm{N}_{2}}{\mathrm{~N}_{1}}} \times \frac{100}{1}$

where $\mathrm{P}$ is potency, $\mathrm{E}$ is efficacy, $\mathrm{N}_{1}$ is the number of treated seeds, $\mathrm{N}_{2}$ the number of seeds with fungal growth. The effect of the treatment on the germinability of the seeds was determined by the decrease in mean percentage germination of the seeds of the variety as the concentration increases per fungicide type, using the formula - : MPG

$=\frac{\mathrm{N}_{1}-\mathrm{N}_{2}}{\mathrm{~N}_{1}} \times \frac{100}{1}$ where $\mathrm{MPG}$ is the mean

percentage germination, $\mathrm{N}_{1}$ is the number of treated seeds plated, $\mathrm{N}_{2}$ the number of un-germinated seeds .Each experiment was replicated three times.

\section{RESULTS AND DISCUSSION}

As shown in Table 1, in the soaking method, at the concentration $50 \mathrm{mg} / \mathrm{ml}$, all the fungicides Bavistin(BA), Benlate(BE), Fernasan-D(FND), Apron Plus 50 Ds (AP), and Dithane-M45(DI) controlled completely, whereas in the slurry method, the fungicides controlled completely all the fungi associated with the seeds of the variety at the concentrations $40 \mathrm{mg} / \mathrm{gseed}$ and $50 \mathrm{mg} / \mathrm{gseed}$. The control showed that the following percentages of seed-borne fungi were recovered from the seeds of the variety: Bipolaris oryzae $50.9 \%$;Fusarium moniliforme 37.3\%; Fusarium oxysporum 38.9\% ; Aspergillus flavus 8.2\% ; Aspergillus niger 4.5\%; Aspergillus terreus 3.2\%; Curvularia lunata $0.5 \%$;
Trichoderma harzianum $16.2 \%$; Penicillium sp 0.8 and Alternaria tenuis $1.0 \%$. All the fungicides were effective against all the seed-borne fungi after seven days of incubation $\mathrm{P}<0.05$. However, at lower concentration of $20 \mathrm{mg} / \mathrm{ml}$ using the soaking method, they were not very effective against Bipolaris oryzae (\% recovery above $10 \%)$. Thus, the best treatment should be from concentration above $20 \mathrm{mg} / \mathrm{ml}$ or $20 \mathrm{mg} / \mathrm{gseed}$ depending on the method to be used for treatment with the fungicide. Generally, slurry method was better than the soaking method.

Ibiam et al, (2006), reported that Benlate, Bavistin, Apron Plus 50 Ds , Fernasan -D, and Dithane M-45, controlled seed-borne fungi of rice and improved seed germination of rice variety, Faro 15, in vitro. Dodan et al (1991), used Bavistin (Carbendazim) to eradicate $F$ moniliforme causal agent of foot-rot and bakanae disease of rice. Geetha and Sivaprakasam (1993), reported that Bavistin (Carbendazim) was effective against Bipolaris oryzae, the causal agent of brown leaf-spot of rice. Dry seed treatment with Bavistin and Fernasan-D, was reported to have increased seedling population and shoot-length, by Lakshmanan and Mohan (1988). They also reported that wet seed treatment with Thiram (Fernasan-D), increased seedling population.

Raza et al, (1993), reported that seed treatment with Benomyl (Benlate) inhibited the growth and sporulation of $F$ moniliforme in vitro, while it enhanced the germination of seeds and reduced fungal infection effectively. Ouf (1993), also controlled seed-borne Aspergillus niger, A flavus, Penicillium $s p$ and Fusarium $s p$ when treated with the chemical. Narmada and Kang (1992), reported that laboratory evaluation of seed treatment of rice with Carbendazim (Bavistin) controlled seed-rot, and significantly decreased seedling mortality. Mancozeb (Dithane M-45) significantly reduced rice seed-borne infection by Drechslera oyzae (Bipolaris oryzae) (Rao and Ranganathaiah, 1988). As shown in Fig.1, in the soaking method, mean percentage germination was not below $71 \%$ at all the concentrations of the fungicides, except at the concentration $20 \mathrm{mg} / \mathrm{ml}$ which was $62.8 \%$ for Benlate treated seeds, whereas in the slurry method, the mean percentage germination was not below $82 \%$ at all the concentrations of the fungicides. The mean percentage seed germination for the control was $97 \%$.The fungicides had no significant effect on the germination of seeds, for two methods used in this study $\mathrm{P}>0.05$. However, the variation in the mean percentage germinations could be attributed to the effect of the various fungicides, on the seeds. 
TABLE 1. EFFECT OF SEED-DRESSING FUNGICIDES ON FUNGI ASSOCIATED WITH SEEDS OF FARO 29

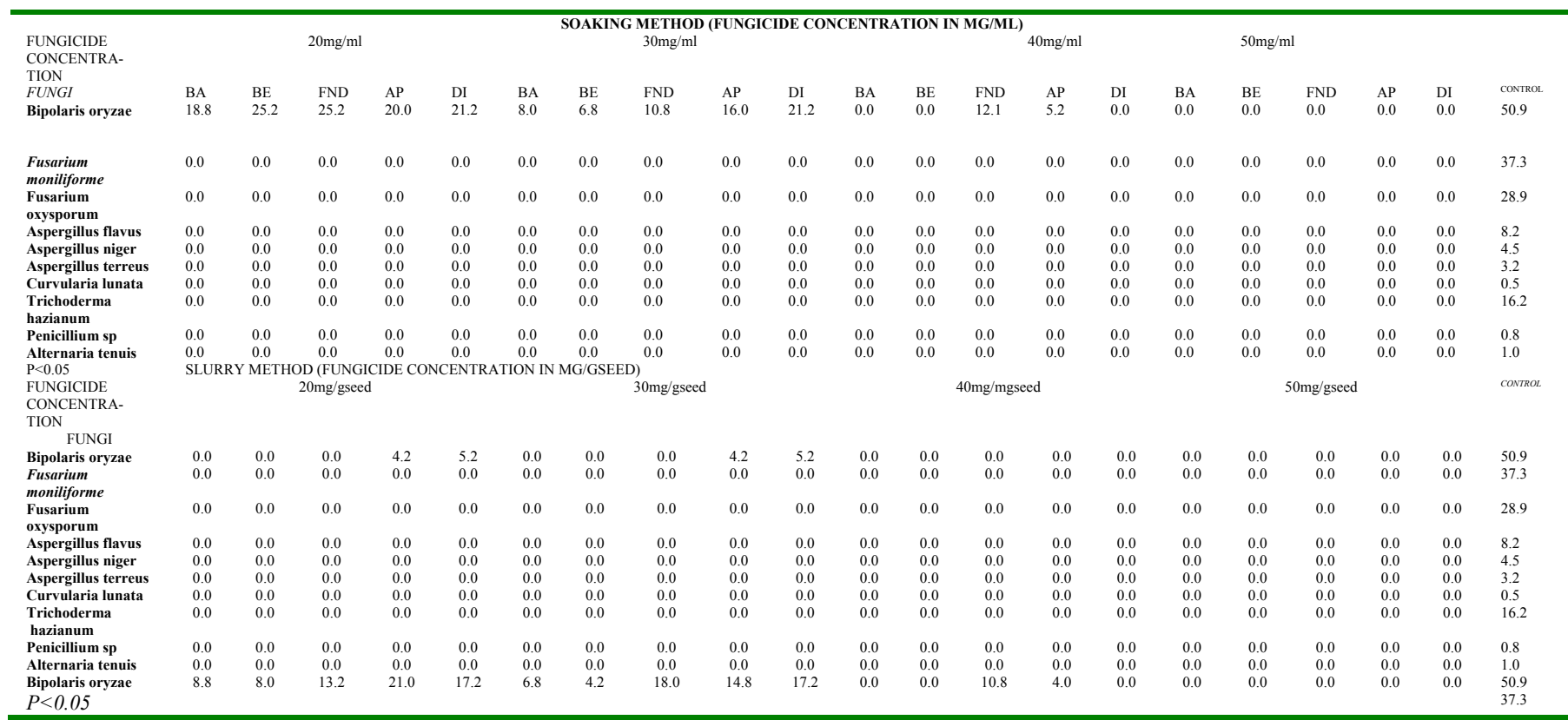
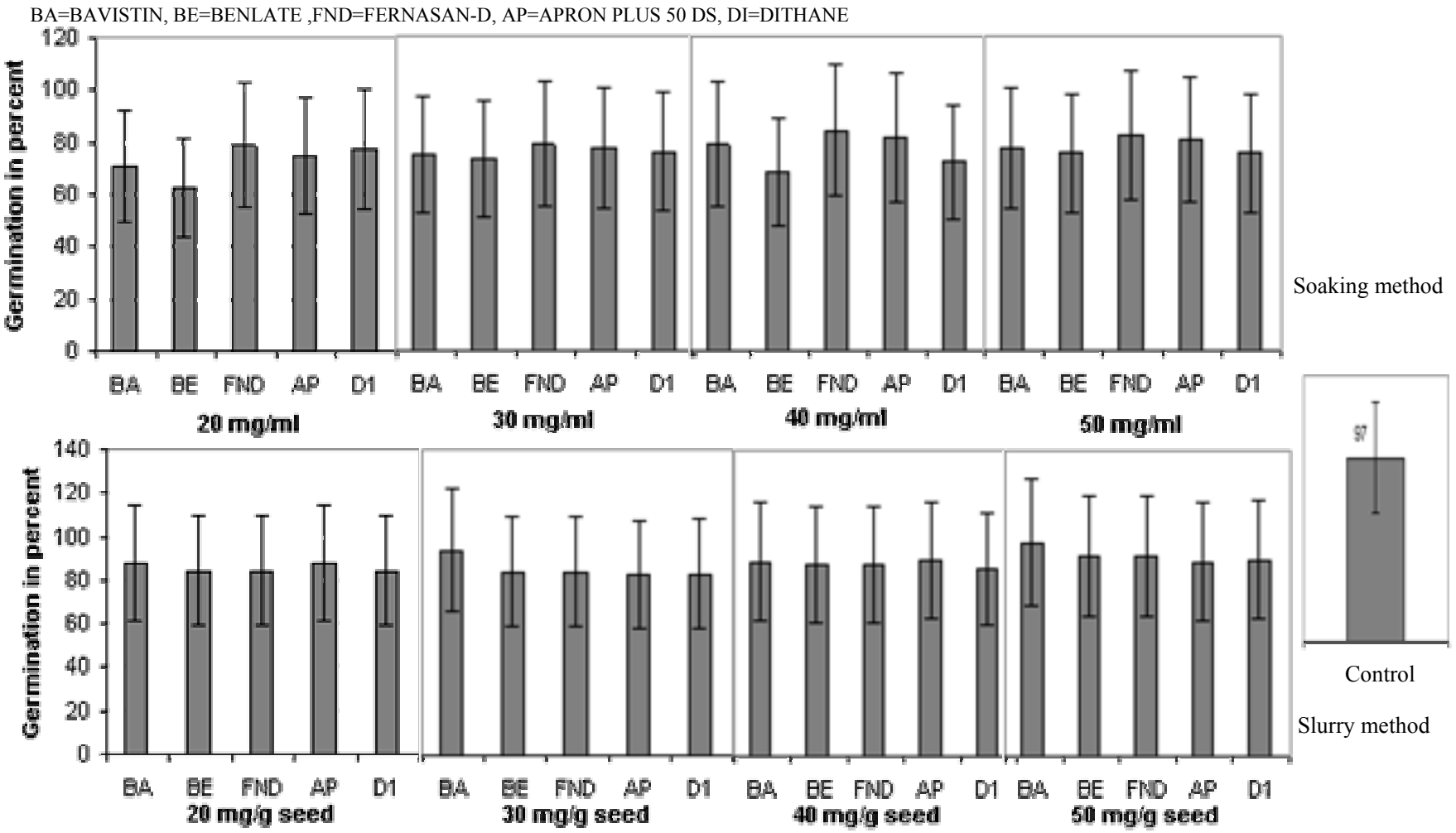

Fig. 1 Effect of seed-dressing fungicides on the germination of the seeds of 
Benomyl controlled $F$ oxysporum on Salvia seeds and Palms (Cho et al , 1988), and prevented the germination of conidia of two wild isolates of Trichoderma harzianum (Papavizas et al 1981). Ibiam and Arinze (2000), used Apron Plus 50 DS to control spore germination and vegetative growth of $F$ moniliforme.

According to Ibiam et al, 2006), Benomyl, Bavistin, Fernasan-D and Apron Plus 50 DS, being systemic fungicides would have inactivated or killed the pathogens in the seeds or the seedlings, as the seeds germinated. They also stated that these fungicides could have increased the resistance of the seeds or seedlings, or must have interfered with pathogenic process, thus, blocking the development of symptoms in the seeds or seedlings. These fungicides used in the soaking method would have penetrated the seeds, and arrested the metabolic processes, some of them acting on specific or localized sites of action in the fungi, thus, stopping further action of the fungi (Ibiam et al, 2006). The inability of the fungicides to destroy some of the fungi completely at lower concentrations could stem from the fact that at these concentrations, the metabolic processes of the fungi could not be arrested completely. However, as the concentrations increased, these fungi were completely destroyed due to complete arrest of the metabolic activities of the fungi which included enzymatic activities in the fungi. It could also be that at lower concentrations, plants could metabolize the fungicides into more active compounds. It could be possible that at lower concentrations, the concentrations of the compounds to which the fungicides were metabolized were lower, and thus, increased as the concentration of the fungicides increased, inhibiting the activities of the organisms.

\section{REFERENCES}

Abda-Elmoity, TH; Papavizas, GC ; Shatta, M $\mathrm{N}(1982)$. Induction of new isolates of $T$ harzianum tolerant to fungicides and their experimental control on white rot of onion Phytopathology 72:396-400.

Burnett, HL; Hunter, BB (1991). Illustrated Genera of Imperfecti Fungi . $4^{\text {th }}$ Edition Minneapolis: Burgess Publishing Co.241pp.

Cho, S H; Kang, H D.; Kim, CH (1988). Fusarium moniliforme associated with foreign seeds o twenty-three plant species from six countries. Korean Journal of Plant Pathology 4(4) : 319324.

Dodan, DS; Singh, R ; Sunder, S (1991). Survival of Fusarium moniliforme in infected rice grains and its chemical control. Indian Journal of Mycology and Plant Pathology 24 (2) : 135138.

Gangopadyay, S.; Kapoor, KS (1975). Control of damping-off of solanaceous vegetable in Kulu valley Pesticides 40:41-42.

Gangopadyay, S; Kapoor, K S (1977). Control of Fusarium wilt of okra with seed treatment Indian Journal of Mycology and Plant Pathology 7 : 147-149.

Geetha, D.; Sivaprakasam, K (1993). Treating rice seeds with fungicides and antagonists to control seed-borne diseases. International Rice Research Notes. 18 (3) 30-31.

Ibiam, OFA.; Arinze, A E .(2000). Optimization of the conditions for controlling and treating the pos-harvest soft-rot of carrot (Daucus carota L) tubers caused by $F$ moniliforme Sheldon. Plant Prod. Res. Journal, 5: 44-50.

Ibiam, O F A; Umechuruba, C I; Arinze, A E .(2000).Field Evaluation of Seed-Dressing Fungicides, Bavistin, Benlate Fernasan-D and Apron Plus 50 DS associated with three rice varieties Faro 12, Faro 15, and Faro 29. Journal of Health and Visual Sciences 2. 96-106.

Ibiam, O F A; Umechuruba, C I; Arinze, A E (2006).Evaluation of the Efficacy of SeedDressing fungicides (Bavistin, Benlate, Fernasan-D, Apron Plus 50 DS, and DithaneM45) In the Control of Seed-Borne Fungi of Rice (Oryzae sativa L) Variety Faro 15 In Vitro . Sciencia Africana .5 (1) 1-10.

Lakshmanann, P and Mohan S (1988). Effect of seed treatments on brown spot disease and their influence on rice seedlings .Madras Agricultural Journal 75(1-2) : 57-58.

Misra, A K; and D-haran, V (1990). Efficacy of fungicides-XLVI: Effect of fungicidal seed treatment against heavy inoculum pressure of fungi causing discoloration of paddy seeds. Indian Phytopathology 43 (2) 175-178.

Narmada, S and Kang, M S (1992). Effect of seed treatment on seed rot, germination and seeding mortality on rice. Seed Research 20 (1) : 56-57.

Ou, S.H(1987). Rice Diseases. CAB International, U. $\mathrm{K}$.

\footnotetext{
* Corresponding author: Ibiam O.F.A.
} 
Ouf, S A (1993). Mycroflora and population dynamics of some seed-borne fungi in relation to fungicide Benlate. Zentralblaltfur Mikrobiologic 148 (18): 570-581.

Papavizas, G C ; Lewis, J A ; Abda-Elmoity, T H (1988). Evaluation of new biotypes of $T$ harzianum for tolerance to benomyl and enhanced bio-control capability. Phytopathology, 72: 176-132.
Ramanithan, M A and Sivaprakasam, K (1994). Effect of seed treatment with antagonists and fungicides on seed viability and seedling vigour in Chile. Seed Research.20 (2):134-137.

Rao, S S and Ranganathanaiah, G (1988). Control of seed-borne infection of Drechslera oryzae in paddy by seed treatment. Seed Research 16 (2) :193-199.

Raza, T; Ahmed, M I; Nasir, M A (1993). Extent of infection of Fusarium moniliforme Sheldon in different rice seed samples and in vitro effect of certain fungicides on the fungus. Sarhad Journal of Agriculture 9 (3):231-233. 